\title{
Study of Gels of Molybdenum with Cerium in the Preparation of Generators of ${ }^{99} \mathrm{Mo}-{ }^{99 \mathrm{~m}} \mathrm{Tc}$
}

\author{
Vanessa Moraes, Bárbara Marczewski, Carla Roberta Dias and João Alberto Osso Junior* \\ Centro de Radiofarmácia do IPEN-CNEN/SP
}

\begin{abstract}
${ }^{99 m}$ Tc has ideal nuclear properties for organ imaging in nuclear medicine, and it is obtained from the ${ }^{99} \mathrm{Mo}-{ }^{99 m} \mathrm{Tc}$ generator. Four different types of generators are available: chromatographic that uses ${ }^{99}$ Mo from fission of uranium; $\mathrm{MEK}$ solvent extraction; $\mathrm{Tc}_{2} \mathrm{O}_{7}$ sublimation; gel chromatographic. This work presents the preparation of gel generators of molybdenum with cerium and characterization of the gels: mass ratio between molybdenum and cerium, structure, size of particles and elution percentage of ${ }^{99 m}$ Tc after irradiating the gels. Eight gels were prepared at the same temperature of $50{ }^{\circ} \mathrm{C}$ with concentrations of $\mathrm{NaOH}$ of 2 and $4 \mathrm{~mol} / \mathrm{L}$, mass ratio of 0.31 and 0.38 and final $\mathrm{pH}$ of 3.5 and 4.5. The analysis of the results proved that these gels are not adequate for preparation of the generators of ${ }^{99} \mathrm{Mo}^{-{ }^{99 m}} \mathrm{Tc}$, since the elution percentages are low, when compared with the gel of molybdenum with zirconium.
\end{abstract}

Key words: Radioisotopes, technetium 99 m, molybdenum-99, gel generator

\section{INTRODUCTION}

The basic requirements of radionuclides to be used in Nuclear Medicine are a physical half-life compatible with the studies to be carried out; low toxicity; adequate radionuclidic, radiochemical and chemical purities; high specific activity; fast availability and low price; possibility of labeling for preparation of radiopharmaceuticals. ${ }^{1}$

When it is necessary to obtain three-dimensional and dynamic images of organs or tissues of patients, the SPECT (single photon emitter computadorized tomography) technique of is used. $^{2,3}$

Radioisotopes used in this technique must have the following characteristics: emit gamma radiation with energy between 100 and $300 \mathrm{keV}$, decay by electron capture or isomeric transition, possess adequate physical half-life for the physiological study of interest, not emit corpuscular radiation to minimize the dose of radiation for the patient. Some radioisotopes usually used in SPECT are ${ }^{81 \mathrm{~m}} \mathrm{Kr}(13.0 \mathrm{~s}),{ }^{99 \mathrm{~m}} \mathrm{Tc}(6.0 \mathrm{~h}),{ }^{123} \mathrm{I}(13.0 \mathrm{~h}),{ }^{77} \mathrm{Br}$ $(57.0 \mathrm{~h}),{ }^{111} \mathrm{In}(67.9 \mathrm{~h}),{ }^{201} \mathrm{Tl}(73.0 \mathrm{~h}),{ }^{67} \mathrm{Ga}(78.3$ h), ${ }^{131} \mathrm{I}(8.0 \mathrm{~d}) .{ }^{4}$

${ }^{99 \mathrm{~m}} \mathrm{Tc}$ is the isotope most commonly used in Nuclear Medicine, because of its nuclear characteristics: short half-life $(6.04 \mathrm{~h})$, emission of gamma radiation of low energy $(140 \mathrm{keV})$, absence of beta emission, $100 \%$ of decay by isomeric transition to ${ }^{99} \mathrm{Tc}$. Labeled molecules with ${ }^{99 \mathrm{~m}} \mathrm{Tc}$ are used for visualization of kidneys, liver, lungs and skeleton.

A ${ }^{99} \mathrm{Mo}^{-99 \mathrm{~m}} \mathrm{Tc}$ generator is a system formed with these two radioisotopes, where the molybdenum, by radioactive decay, produces the technetium that must be separated from molybdenum. ${ }^{99}$ Mo can be produced by several nuclear reactions in particle

\footnotetext{
* Author for correspondence
} 
accelerators or nuclear reactors. Currently, four different types of preparation of ${ }^{99} \mathrm{Mo}^{-99 \mathrm{~m}} \mathrm{Tc}$ generators are available based on the separation techniques: column chromatography with alumina, which uses ${ }^{99} \mathrm{Mo}$ from fission, solvent extration using methyl ethyl ketone, sublimation of the $\mathrm{Tc}_{2} \mathrm{O}_{7}$, and a chromatographic gel type generator that contains molybdenum.

Between 1978 and 1988, in Australia, the research for the attainment of the ${ }^{99} \mathrm{Mo}^{-99 \mathrm{~m}} \mathrm{Tc}$ generator by the gel process was developed. ${ }^{99} \mathrm{Mo}$ is produced by the $(\mathrm{n}, \gamma)$ reaction and is incorporated into a gel of zirconium molybdate. The specific activity of ${ }^{99} \mathrm{Mo}$ is low, but adequate for the preparation of the generators in countries with limited infrastructure. In the literature, preparations of gels are reported replacing zirconium with:

* Cerium (IV), which is efficient in the loss of elution efficiency provoked by radiolysis;

* Titanium, prepared in countries such as Argentina, Czech Republic, India, Peru and Vietnam;

* Mixture of $\mathrm{MoO}_{3}-\mathrm{V}_{2} \mathrm{O}_{5}$ - $\mathrm{SiC}$, used in Hungary;

* Zirconium molybdate, developed in Egypt, can be eluted with distilled water or saline solution;

* 12-molybdenumcerate (IV) also developed in Egypt. $^{5,6}$

\section{MATERIALS AND METHODS}

* Molybdenum oxide $\left(\mathrm{MoO}_{3}\right)$, analytical grade Merck;

* Cerium sulphate tetrahydrate $\left[\mathrm{Ce}\left(\mathrm{SO}_{4}\right)_{2} \cdot 4\right.$ $\mathrm{H}_{2} \mathrm{O}$, analytical grade Merck;

* Sodium hidroxide $(\mathrm{NaOH})$, analytical grade Merck;

* Nitric acid $\left(\mathrm{HNO}_{3}\right)$, analytical grade Merck;

* Sodium carbonate $\left(\mathrm{Na}_{2} \mathrm{CO}_{3}\right)$, analytical grade Merck;

* Distilled water.

\section{Procedure}

$\mathrm{MoO}_{3}$ was dissolved in $\mathrm{NaOH}$, the $\mathrm{pH}$ was adjusted to 4.0 with $\mathrm{HNO}_{3}$, the solution was stirred and warmed to $50{ }^{\circ} \mathrm{C}$. Separately, $\mathrm{Ce}\left(\mathrm{SO}_{4}\right)_{2} \cdot 4 \mathrm{H}_{2} \mathrm{O}$ was dissolved in $0.1 \mathrm{~mol} / \mathrm{L} \mathrm{H}_{2} \mathrm{SO}_{4}$, the $\mathrm{pH}$ of the solution was adjusted to 1.5 with $\mathrm{Na}_{2} \mathrm{CO}_{3}$, and the solution was added dropwise to the molybdenum solution. The mixture was stirred, and the final $\mathrm{pH}$ was adjusted with $\mathrm{NaOH}$ in the same concentration used initially. The mixture remained in agitation until being filtered, and the gel was dried. After drying, the gel is washed three times with saline solution to remove the fines and dried.

\section{Determination of the size of the gel particles}

The granulometry was determined by swing with a magnetic agitator of sieve, series 9802, Bertel Metallurgic Industry Ltda., which measures the distribution of the size of particles through a measured of mass. A gel adequate for the preparation of the molybdenum generator must possess particles of size between 0.106 and 0.150 $\mathrm{mm}$. If the particles are smaller than $0.106 \mathrm{~mm}$, they can pass through the porous plate that is placed in the lower part of the glass column of the generator and, if the particles are larger than 0.150 $\mathrm{mm}$, elution channels may form.

\section{X-Rays diffraction}

The equipment used for this procedure is a BrukerACS, model D8 Advance X-ray diffratometer with a $40 \mathrm{kV}$ tension, $20 \mathrm{~mA}$ electric intensity copper source, monochromator beam and fixed, glass plate, $\mathrm{K} \alpha$ filter and window with a $1 \mathrm{~mm}$ beam of the Departamento de Engenharia Metalúrgica of IPEN-CNEN/SP. This technique has been used to determine the structure of the gel, which allows one to determine whether the gel is amorphous or crystalline.

${ }^{99}$ Mo- ${ }^{-99 m}$ Tc generators prepared with molybdenum and cerium must have an amorphous structure because this type of structure provides greater capacity for ion exchange, that is, the capacity to remove the technetium that was produced by the radioactive decay of the molybdenum when the generator was eluted.

\section{Determination of the amount of molybdenum and cerium in the gel}

The amount of molybdenum and cerium in the gels was determined by neutron activation analysis. The technique consists of the interaction of a material with neutrons and the posterior measurement of the induced radioactivity. Generally, the irradiation is carried out with thermal neutrons generated by a nuclear reactor, and the radioactivity of each radionuclide produced is measured by gamma ray spectroscopy. Equal masses of gel and the molybdenum $\left(\mathrm{MoO}_{3}\right)$ and cerium $\left(\mathrm{CeO}_{2}\right)$ standards were irradiated at the same time in the IEA-R1 reactor of IPEN-CNEN/SP with a neutron flux of $5 \times 10^{11} \mathrm{n} \cdot \mathrm{cm}^{-2} \cdot \mathrm{s}^{-1}$. 


\section{Irradiation of the gel}

Gels of molybdenum with cerium were irradiated in the IEA-R1 reactor of the IPEN-CNEN/SP during one hour with a neutron flux of $1,0 \times 10^{13}$ n. $\mathrm{cm}^{-2} \cdot \mathrm{s}^{-1}$.

\section{${ }^{99}$ Mo- ${ }^{99} \mathrm{~m}$ Tc Generators}

The generators were prepared using glass columns with a porous plate, in which alumina and the irradiated gels were placed.

\section{${ }^{99}$ Tc Elution}

This process consisted of passing saline solution through the irradiated gel to remove the technetium.

Determination of the radioisotopes in the eluate Radioisotopes in the eluate were determined by gamma ray spectroscopy using a Germanium hiperpure (HP), model GX1518, detector, Canberra, connected to an acquisition system with data handling by microcomputer, program GENIE
- PC.

\section{RESULTS AND DISCUSSION}

\section{Preparation of the gels}

Molybdenum with cerium gels were prepared at 50 ${ }^{\circ} \mathrm{C}$ and the variables studied in its preparation are presented in Table 1.

\section{Determination of the amount of molybdenum in the gels}

The percentage of molybdenum in the gels was determined by neutron activation analysis, and the results are presented in Table 2.

\section{Determination of the amount of cerium in the} gels

The percentage of cerium in the gels was determined by neutron activation analysis and the results are presented in Table 3.

Table 1 - Variables studied in the preparation of molybdenum with cerium gels.

\begin{tabular}{cccc}
\hline Assay & $\begin{array}{c}\text { NaOH } \\
\text { Concen- } \\
\text { tration }\end{array}$ & $\begin{array}{c}\text { Mass } \\
\text { ratio } \\
\text { Mo/Ce }\end{array}$ & $\begin{array}{c}\text { Final } \\
\text { pH }\end{array}$ \\
\hline $\mathrm{Ce}-01$ & $2 \mathrm{~mol} / \mathrm{L}$ & 0.31 & 3.5 \\
$\mathrm{Ce}-02$ & $4 \mathrm{~mol} / \mathrm{L}$ & 0.31 & 3.5 \\
$\mathrm{Ce}-03$ & $2 \mathrm{~mol} / \mathrm{L}$ & 0.38 & 3.5 \\
$\mathrm{Ce}-04$ & $4 \mathrm{~mol} / \mathrm{L}$ & 0.38 & 3.5 \\
$\mathrm{Ce}-05$ & $2 \mathrm{~mol} / \mathrm{L}$ & 0.31 & 4.5 \\
$\mathrm{Ce}-06$ & $4 \mathrm{~mol} / \mathrm{L}$ & 0.31 & 4.5 \\
$\mathrm{Ce}-07$ & $2 \mathrm{~mol} / \mathrm{L}$ & 0.38 & 4.5 \\
$\mathrm{Ce}-08$ & $4 \mathrm{~mol} / \mathrm{L}$ & 0.38 & 4.5 \\
\hline
\end{tabular}

Table 2 - Percentage of molybdenum in the molybdenum with cerium gels.

\begin{tabular}{cc}
\hline Assay & \% Mo \\
\hline Ce-01 & $7.8 \pm 7.5$ \\
Ce-02 & $8.4 \pm 5.9$ \\
Ce-03 & $9.2 \pm 5.8$ \\
Ce-04 & $20.6 \pm 2.5$ \\
Ce-05 & $9.8 \pm 4.8$ \\
Ce-06 & $11.1 \pm 5.6$ \\
Ce-07 & $13.9 \pm 7.4$ \\
Ce-08 & $6.9 \pm 20.2$ \\
\hline
\end{tabular}


Table 3 - Percentage of cerium in the molybdenum with cerium gels.

\begin{tabular}{lc}
\hline Assay & \% Ce \\
\hline Ce-01 & $42.5 \pm 3.3$ \\
Ce-02 & $41.8 \pm 3.3$ \\
Ce-03 & $41.4 \pm 3.2$ \\
Ce-04 & $42.3 \pm 3.3$ \\
Ce-05 & $44.5 \pm 3.5$ \\
Ce-06 & $43.0 \pm 3.4$ \\
Ce-07 & $39.2 \pm 3.1$ \\
Ce-08 & $37.4 \pm 2.9$ \\
\hline
\end{tabular}

From the results in Table 3, it can be observed that the $\mathrm{Ce}-05$ preparation presented the highest cerium percentage in the gel, although all the preparations presented high cerium percentages when compared with the molybdenum percentage. From the results in Table 2, it can be seen that the amount of molybdenum was small and that low ${ }^{99 \mathrm{~m}} \mathrm{Tc}$ activities would be obtained.

\section{Determination of the gel structure}

The X-ray diffractogram for the molybdenum and cerium gels showed that they were amorphous (Fig. 1). This diffractogram represents the X-ray diffraction for all the gels of molybdenum with cerium and it can be observed that it does not have peaks of semi-cristalinity. Table 4 presents the structure of the gels of molybdenum with cerium.

\section{Determination of the size of the gel particles}

The size distribution of particles in the molybdenum with cerium gels can be seen in Fig.2.

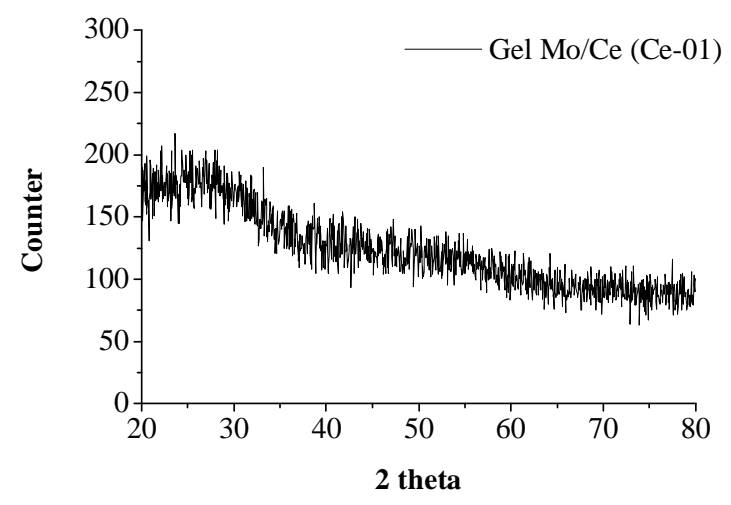

Figure 1 - X-ray diffractogram of the molybdenum with cerium gel for the $\mathrm{Ce}-01$ preparation.

Table 4 - Structure of molybdenum with cerium gels.

\begin{tabular}{ll}
\hline Assay & Structure \\
\hline Ce-01 & Amorphous \\
$\mathrm{Ce}-02$ & Amorphous \\
$\mathrm{Ce}-03$ & Amorphous \\
$\mathrm{Ce}-04$ & Amorphous \\
$\mathrm{Ce}-05$ & Amorphous \\
$\mathrm{Ce}-06$ & Amorphous \\
$\mathrm{Ce}-07$ & Amorphous \\
$\mathrm{Ce}-08$ & Amorphous \\
\hline
\end{tabular}




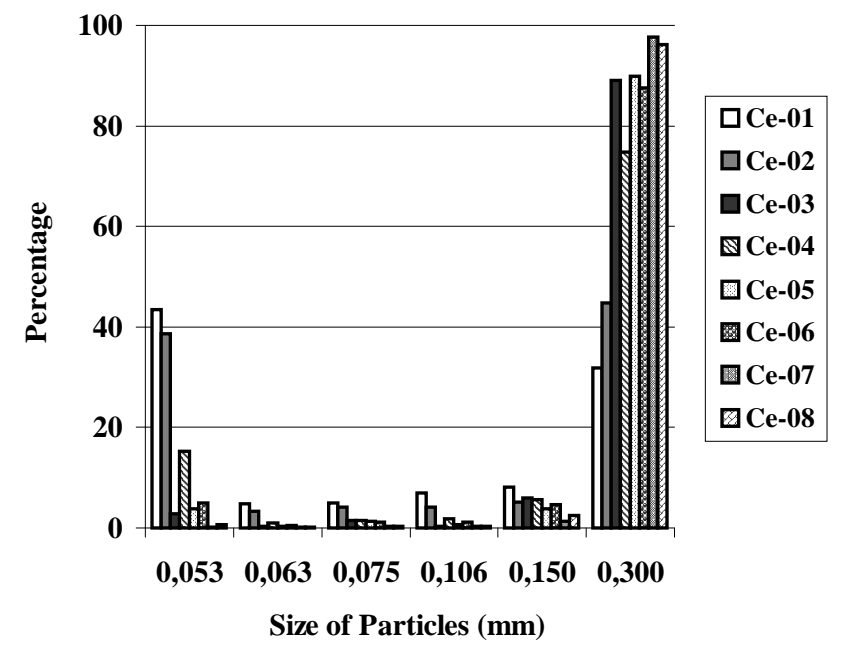

Figure 2 - Particle sizes of the molybdenum with cerium gels.

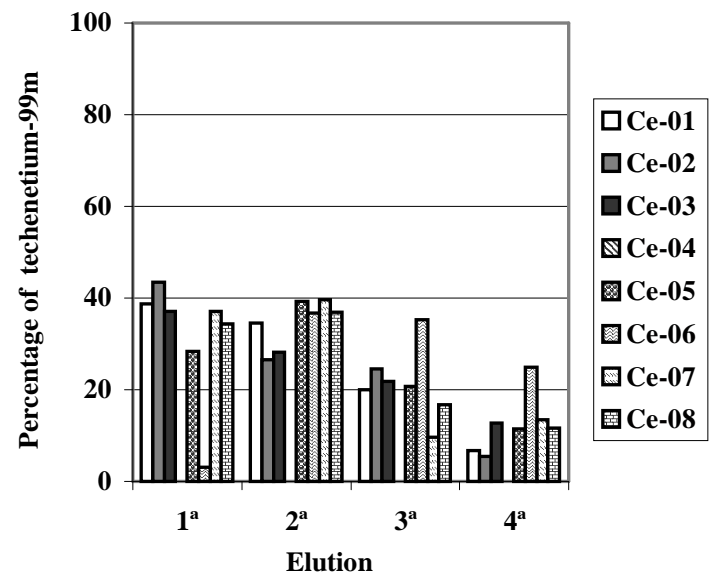

Figure 3 - ${ }^{99 \mathrm{~m}} \mathrm{Tc}$ elution percentage in the ${ }^{99} \mathrm{Mo}-{ }^{99 \mathrm{~m}} \mathrm{Tc}$ generator prepared using molybdenum with cerium gels.

The molybdenum with cerium gels of the Ce 03, 05, 06, 07 and 08 preparations possessed more than $80 \%$ of their particles with size of $0.300 \mathrm{~mm}$ (Fig. 3), while in the Ce-04 preparation, over $75 \%$ of particles possessed this size. The consequence of this fact was the formation of channels for the preferential elution of ${ }^{99 \mathrm{~m}} \mathrm{Tc}$. For the Ce-01 preparation, more than $40 \%$ of its particles had a diameter of $0.053 \mathrm{~mm}$. They were very small for the preparation of the generator and the gel was able to pass through the porous plate, contaminating the ${ }^{99 \mathrm{~m}} \mathrm{Tc}$ eluate.

\section{${ }^{99 \mathrm{~m}} \mathrm{Tc}$ elution of the generator prepared with irradiated gels}

Fig. 3 presents the percentage of elution of the generators prepared with the molybdenum with cerium and molybdenum with zirconium gels. As can be observed, the $\mathrm{Ce}-02$ preparation was the only one that eluted more than $40 \%$ of the ${ }^{99 \mathrm{~m}} \mathrm{Tc}$ in the first elution, and all the percentages of ${ }^{99 \mathrm{~m}} \mathrm{Tc}$ eluted were low when compared with the percentage of elution of ${ }^{99 \mathrm{~m}} \mathrm{Tc}$ from the molybdenum with zirconium gel, which was $81.7 \%$ in the first elution. From these data, one 
can conclude that the cerium gels do not present adequate characteristics for the preparation of the ${ }^{99} \mathrm{Mo}^{-}{ }^{99 \mathrm{~m}} \mathrm{Tc}$ generator.

\section{RESUMO}

$\mathrm{O}{ }^{99 \mathrm{~m}} \mathrm{Tc}$ é o radiofármaco mais utilizado em Medicina Nuclear. Ele é obtido do gerador de ${ }^{99} \mathrm{Mo}^{99 \mathrm{~m}} \mathrm{Tc}$ e existem quatro tipos diferentes de geradores: cromatográfico que utiliza ${ }^{99} \mathrm{Mo}$ de fissão; extração por solvente com MKT; sublimação do heptaóxido de tecnécio; cromatográfico tipo gel.

Este trabalho apresenta a preparação de geradores tipo gel de molibdênio com cério, a caracterização desses géis com relação à quantidade de molibdênio e de cério, sua estrutura, tamanho das partículas e porcentagem de eluição do ${ }^{99 \mathrm{~m}} \mathrm{Tc}$ após o gel ser irradiado.

Foram preparados oito géis na temperatura de $50^{\circ} \mathrm{C}$ com concentração de $\mathrm{NaOH}$ de 2 e $4 \mathrm{~mol} / \mathrm{L}$, relação de massa de 0,31 e 0,38 e pH final de 3,5 e 4,5 .

A análise dos resultados comprovou que esses géis não são adequados para preparação dos geradores de ${ }^{99} \mathrm{Mo}^{-}{ }^{99 \mathrm{~m}} \mathrm{Tc}$, já que as porcentagens de eluição são baixas, quando comparadas com o gel de molibdênio com zircônio.

\section{REFERENCES}

Tubis, M. and Wolf, W. (1976), Radiopharmacy. New York : John Wiley and Sons. pp. 263-5.

Saha, G. B. (1998), Fundamentals of nuclear pharmacy. Cleveland: Springer.

Weiner, R. E. and Thakur, M. L. (1995), Metallic radionuclides: applications in diagnostic and therapeutic nuclear medicine. Rad. Acta, 70/71, 273-287.

Osso Jr., J. A. (1986), ${ }^{77} \mathrm{Br}$ Isotope production for medical use. Tese (Doutorado), University of Manchester, London.

Vans, J. V.; Moore, P. W.; Shying, M. E. and Sodeau, J. M. (1978), Zirconium molybdate gel as a generator for technetium ${ }^{-99 m}-\mathrm{I}$. The concept and its evaluation. Appl. Radiat. Isot., 38, 19-23.

El-Kolay, M. T.; Talaat, H. and Botros, N. (1996), A modified ${ }^{99} \mathrm{Mo}^{99 \mathrm{~m}} \mathrm{Tc}$ generator on zirconium molybdo-phosphate - ${ }^{99}$ Mo gel. In: Conference of Nuclear Sicences and Applications, 6., Egito, Proceedings... Egito. v. 3. pp. 124.

Received: July 05, 2005;

Revised: July 14, 2005; Accepted: August 01, 2005. 